\title{
Deadwood stocks increase with selective logging and large tree frequency in Gabon
}

\author{
BEN S. CARLSON ${ }^{1}$, SALLY E. KOERNER ${ }^{1}$, VINCENT P. MEDJIBE ${ }^{1,2}$, LEE J. T. WHITE ${ }^{2,3,4}$ \\ and JOHN R. POULSEN ${ }^{1}$ \\ ${ }^{1}$ Nicholas School of the Environment, Duke University, PO Box 90328, Durham, NC 27708, USA, ${ }^{2}$ Agence Nationale des Parcs \\ Nationaux, Batterie IV , Libreville BP 20379, Gabon, ${ }^{3}$ Institut de Recherche en Ecologie Tropicale, Libreville BP 1354, Gabon, \\ ${ }^{4}$ African Forest Ecology Group, School of Natural Sciences, University of Stirling, Stirling, UK
}

\begin{abstract}
Deadwood is a major component of aboveground biomass (AGB) in tropical forests and is important as habitat and for nutrient cycling and carbon storage. With deforestation and degradation taking place throughout the tropics, improved understanding of the magnitude and spatial variation in deadwood is vital for the development of regional and global carbon budgets. However, this potentially important carbon pool is poorly quantified in Afrotropical forests and the regional drivers of deadwood stocks are unknown. In the first large-scale study of deadwood in Central Africa, we quantified stocks in 47 forest sites across Gabon and evaluated the effects of disturbance (logging), forest structure variables (live AGB, wood density, abundance of large trees), and abiotic variables (temperature, precipitation, seasonality). Average deadwood stocks (measured as necromass, the biomass of deadwood) were $65 \mathrm{Mg}^{-1}$ or $23 \%$ of live AGB. Deadwood stocks varied spatially with disturbance and forest structure, but not abiotic variables. Deadwood stocks increased significantly with logging $\left(+38 \mathrm{Mg} \mathrm{ha}^{-1}\right)$ and the abundance of large trees $\left(+2.4 \mathrm{Mg}^{-1}\right.$ for every tree $>60 \mathrm{~cm}$ dbh). Gabon holds $0.74 \mathrm{Pg} \mathrm{C}$, or $21 \%$ of total aboveground carbon in deadwood, a threefold increase over previous estimates. Importantly, deadwood densities in Gabon are comparable to those in the Neotropics and respond similarly to logging, but represent a lower proportion of live AGB (median of 18\% in Gabon compared to $26 \%$ in the Neotropics). In forest carbon accounting, necromass is often assumed to be a constant proportion (9\%) of biomass, but in humid tropical forests this ratio varies from $2 \%$ in undisturbed forest to $300 \%$ in logged forest. Because logging significantly increases the deadwood carbon pool, estimates of tropical forest carbon should at a minimum use different ratios for logged (mean of 30\%) and unlogged forests (mean of $18 \%$ ).
\end{abstract}

Keywords: aboveground biomass (AGB), carbon storage, coarse woody debris (CWD), deadwood, necromass, tropical forest

Received 18 June 2016 and accepted 10 July 2016

\section{Introduction}

Tropical forests store over half the world's forest carbon and are the largest terrestrial source and sink of atmospheric carbon (Dixon et al., 1994; Pan et al., 2011). The disproportionate role tropical forests play in the global carbon cycle and increasing concern over global climate change has intensified research into the stocks and fluxes of tropical forest carbon (Gibbs et al., 2007). Forest carbon is stored in five pools: (i) aboveground live biomass (AGB, biomass with diameter $\geq 10 \mathrm{~cm}$ ); (ii) belowground live biomass; (iii) deadwood (also known as coarse woody debris; dead boles or branches $\geq 10 \mathrm{~cm}$ in diameter); (iv) fine woody debris (branches $<10 \mathrm{~cm}$ in diameter); and (v) soil carbon (IPCC, 2003). Of these five pools, AGB is the most visible, most easily measured, and most studied (e.g., Brown \& Gaston, 1996; Saatchi et al., 2011; Baccini et al., 2012). While knowledge of the environmental and biotic determinants of

Correspondence: John R. Poulsen, tel. 919668 4060,

fax 919613 8061, e-mail: john.poulsen@duke.edu
AGB is advancing rapidly (Lewis et al., 2009; Asner et al., 2010; Larjavaara \& Muller-Landau, 2012; Burton et al., 2016; Shen et al., 2016), knowledge of the stocks, geographic distribution, and drivers of deadwood has progressed more slowly, despite the importance of deadwood to the tropical forest carbon cycle and the critical roles it serves in forest ecosystems (Harmon et al., 1986) by providing nourishment for saproxylic organisms (Stokland et al., 2012) and habitat for many vertebrate and invertebrate species (McGee et al., 1999; Warren \& Bradford, 2012).

Most estimates of tropical forest carbon exclude deadwood (Saatchi et al., 2011; Baccini et al., 2012), or assume that it makes up a constant proportion of AGB (Houghton et al., 2001; Malhi et al., 2006; Saatchi et al., 2007; Lewis et al., 2009). The ratio of necromass - the biomass of deadwood - to biomass (N/AGB) varies from $2 \%$ in undisturbed forest to $300 \%$ in heavily disturbed forest (Palace et al., 2012), but estimates of total carbon stocks most often employ a constant ratio of $9 \%$, likely oversimplifying and underestimating the role of 
deadwood (Chao et al., 2009). The local carbon balance between the AGB and deadwood pools depends on the rate of carbon capture by trees, the rate of carbon transfer from the AGB to the deadwood pool, and the rate of exit from the deadwood pool. Carbon transfer to the deadwood pool usually occurs with tree mortality, but can also occur when trees shed large branches (Chambers et al., 2001). Exit from the deadwood pool is largely controlled by the decomposition rate, but can also be influenced by the mechanical movement of deadwood due to slope position or hydrology (Gale, 2000; Chao et al., 2008), extraction as fuelwood (Sassen et al., 2015), or forest fires (Osone et al., 2016). Local variation in the rates of carbon transfer and exit creates spatial variation of deadwood stocks and N/AGB.

The principal determinants of deadwood stocks and N/AGB can be classified broadly as disturbance, biotic, and abiotic factors. Natural and anthropogenic disturbances alter deadwood pools by increasing tree mortality above the background rate of senescence. While there are many causes of tree mortality (Phillips \& Gentry, 1994), drought (Rice et al., 2004; Phillips et al., 2009), wind (Negrón-Juárez et al., 2010), and logging (Keller et al., 2004; Palace et al., 2007; Pfeifer et al., 2015) are among the most important drivers. Selective logging, in particular, should diminish necromass stocks and N/AGB by removing living trees before they die and augment necromass stocks and N/AGB by generating collateral tree damage and mortality (Medjibe et al., 2011).

Although multiple biotic factors are thought to strongly influence deadwood stocks (e.g., microbial communities and xylophagous fauna), we focus on forest structure variables associated with high density of AGB, including the abundance of large trees (Slik et al., 2013; Bastin et al., 2015) and/or high wood density (Chao et al., 2009). Large pieces of wood with high wood density take longer to decompose than many small, more porous pieces of the same mass; therefore, forests with high AGB have slower wood decomposition rates (Chambers et al., 2000; Chao et al., 2009).

The impact of climatic drivers on deadwood stocks has largely been investigated through studies of the effects of climate on decomposition rates: these studies find that biotic factors are more important than climatic factors, especially at local scales (Weedon et al., 2009; Bradford et al., 2014). Temperature should not strongly affect deadwood stocks because increasing temperatures in the tropics accelerate rates of both productivity and decomposition (Chambers et al., 2000; Raich et al., 2006). On the other hand, precipitation can vary substantially in the tropics and is known to influence AGB (Lewis et al., 2013) and decomposition rates (Progar et al., 2000; but see Chambers et al., 2000). To date, disturbance and forest structure are thought to be more important drivers of tropical deadwood stocks than climate variables.

Deadwood stocks in Central African forests are poorly studied compared to the Neotropics (Palace et al., 2012). Several lines of evidence suggest that deadwood stocks might vary widely between the regions, although the direction of this variation is unknown. Compared to the Neotropics, Central African forests experience lower deforestation rates (Mayaux et al., 1999), less intense selective logging (Malhi et al., 2013), and are typically not affected by cyclones or large blowdowns (Chambers et al., 2012). This less intense disturbance regime might result in relatively small deadwood pools compared to the Neotropics. On the other hand, Central African forests tend to have higher AGB than Neotropical forests and are characterized by lower tree density, greater numbers of large stems, and higher wood density (Lewis et al., 2013; Malhi et al., 2013; Slik et al., 2013). Due to their greater AGB and larger trees, which decay more slowly than small trees, Central African forests might store higher levels of carbon in deadwood and have higher N/AGB than Neotropical forests. Thus, depending on the relative importance of and interactions among deadwood drivers, both deadwood stocks and N/AGB could be higher, lower, or similar in Central African tropical forests compared to Neotropical forests. Understanding the differences or similarities in carbon dynamics between the world's two largest tropical rainforests is an important component of accurate global carbon monitoring.

The goal of this study was to quantify the stocks and evaluate the drivers of deadwood in Central African forests. With samples from 47 sites in Gabon, we examine the effects of disturbance (selective logging), forest structure variables (AGB, wood density, basal area, and density of large trees), and abiotic variables (annual temperature and precipitation) on deadwood stocks and N/AGB. We compare our findings to the more commonly studied Neotropical forests to identify whether regional differences in disturbance or forest structure affect deadwood stocks and N/AGB. Finally, we provide estimates of nationwide deadwood stocks for Gabon as a means of contributing to national and regional carbon accounting and management.

\section{Materials and methods}

\section{Study region}

Gabon, located on the western coast of equatorial Africa, is the second most forested tropical country with $88.5 \%$ forest cover (Sannier et al., 2016). Average temperature is relatively constant over the year and across the country, with a mean of 
$25{ }^{\circ} \mathrm{C}$, a high of $26{ }^{\circ} \mathrm{C}$ between January and March, and a low of $23{ }^{\circ} \mathrm{C}$ between June and August. Mean annual precipitation (MAP) is $1844 \mathrm{~mm}$, but varies seasonally with $80 \%$ of precipitation occurring in two rainy seasons between March-May and September-December. MAP varies nearly threefold between the wet coastal forests $(3200 \mathrm{~mm})$ and the relatively arid interior $(1300 \mathrm{~mm})$. Gabon stores $4 \mathrm{Pg}$ of carbon (C) in above- and belowground biomass, not including deadwood, the second highest carbon density (164 Mg C ha ${ }^{-1}$ ) among tropical countries after Malaysia (179 $\mathrm{Mg} \mathrm{C} \mathrm{ha}^{-1}$; Saatchi et al., 2011). Approximately $54 \%$ of Gabon's forested area is committed to timber production (Laporte et al., 2007), with selective logging removing on average $0.4-0.8$ trees $^{-1}$ (Medjibe et al., 2011).

\section{Sampling sites}

In 2012, the Government of Gabon initiated a national resource inventory (NRI) to quantify and monitor forest resources, with a focus on forest carbon (unpublished data, Gabon National Resource Inventory). NRI sites consist of a single 1-ha forest plot and four 0.16-ha satellite plots. The sites are located in a systematic, random design that captures the variation in forest structure and composition across the country. In each site, field teams inventoried and measured trees $(\geq 10 \mathrm{~cm}$ diameter at breast height, dbh) to estimate site-level AGB. Site-level data on disturbance history (primary, secondary, logged) and edaphic type (terra firma (nonflooded forest), seasonally flooded forest, or swamp forest) were also recorded. During the establishment of the NRI, we selected 47 of the randomly placed NRI sites to sample deadwood. We used maps of logging concessions, protected areas, infrastructure, and precipitation to choose sites that would represent primary, secondary, and logged forest across the west-to-east rainfall gradient. Within these 47 sites, we further identified 16 sites to sample for wood density and void space, again distributing the sites equally among the disturbance categories and across the precipitation gradient (Fig. 1).

\section{Deadwood volume}

Necromass is a product of the volume and density of deadwood. Here, we describe methods for estimating volume, and below, we describe methods for estimating density. At each site, we used the line intercept method to quantify total deadwood volume by establishing four $200 \mathrm{~m}$ transects according to a 'pinwheel' design, in which the transects extend from the corners of the 1 ha plot (sensu Baker et al., 2007; Chao et al., 2008). We chose this design because: (i) the line intercept method can suffer from directional bias of deadwood orientation (Bell et al., 1996), requiring multiple transects per site, and (ii) density estimation involves destructive sampling, which would artificially disturb the long-term monitoring plots. Starting from the southwest corner of the 1 ha plots, we chose a random direction away from the plot, orienting each subsequent transect perpendicular to the previous transect.

Along a total of $36.1 \mathrm{~km}$ of transects (Table S3), we quantified total deadwood volume by measuring the diameters of both fallen (deadwood $\geq 10 \mathrm{~cm}$ dbh on the ground that crossed the transect) and standing (deadwood $\geq 10 \mathrm{~cm}$ dbh located $\leq 10 \mathrm{~m}$ from the line transect) deadwood (Warren \& Olsen, 1964; Van Wagner, 1968). For partially buried fallen deadwood, we estimated the diameter by calculating the geometric mean of the horizontal and vertical diameters (Chao et al., 2008). Using measurements of the diameter of all fallen deadwood traversed by the transect, we calculated the volume of fallen deadwood per ha $\left(\mathrm{m}^{3} \mathrm{ha}^{-1}\right), V_{f}$, following Van Wagner (1968):

$$
V_{f}=\frac{\pi^{2} \times \Sigma d_{i}^{2}}{8 L}
$$

where $d_{i}$ is the measured diameter of each piece of deadwood and $L$ is the length of the transect.

For standing deadwood shorter than $1.37 \mathrm{~m}$, we measured the diameter at the base, $d_{b}$, and at the top, $d_{t}$. For standing deadwood taller than $1.37 \mathrm{~m}$, we used the dbh of the stem as $d_{b}$. To estimate $d_{t}$, we measured the height of the standing deadwood, $h$, with a hypsometer (a hand-held instrument for measuring height), and applied a taper function from Chambers et al. (2000):

$$
d_{t}=1.59 d_{b}\left(h^{-0.091}\right)
$$

With measurements of both $d_{b}$ and $d_{t}$, we calculated the volume $\left(\mathrm{m}^{3}\right)$ of each standing deadwood, $v_{s}$, using Smalian's Formula (Harmon et al., 1986, Eqn 3):

$$
v_{s}=h\left[\frac{\pi\left(d_{b} / 2\right)^{2}+\pi\left(d_{t} / 2\right)^{2}}{2}\right] .
$$

To find the volume of standing deadwood per ha $\left(\mathrm{m}^{3} \mathrm{ha}^{-1}\right)$, $V_{s}$, we summed the volume of all standing deadwood per transect and divided by the area of the transect:

$$
V_{s}=\frac{1}{L \times 20} \sum v_{s_{i}}
$$

where $v_{s_{i}}$ is the volume of the $i$ th standing deadwood, and the width of each belt transect is $20 \mathrm{~m}$.

\section{Wood density and void space}

We sampled wood density of deadwood in 16 of the 47 sites. For each piece of fallen deadwood encountered, we used a chainsaw to cut a radial section from the wood at the point crossed by the line transect. We subsampled plugs from the section, calculated density per plug by dividing the dry weight of the plug by the volume of the plug, and used the average density of all plugs in the radial section as the wood density of the piece of deadwood. To subsample the radial section, we randomly chose one of eight radii (evenly spaced around the radial section), and using a machete, cut out a rectangular plug every $5 \mathrm{~cm}$ from the center to the edge of the radial section along the randomly chosen radius (sensu Keller et al., 2004; Fig. 1a). To estimate the volume of each plug, we measured the height, width, and depth of the plugs in the field. If a plug was not sufficiently rectangular, we measured plug volume using the displacement method (Chave et al., 2006). For wood that was extremely friable, we filled a container of known volume with the material. To measure the 


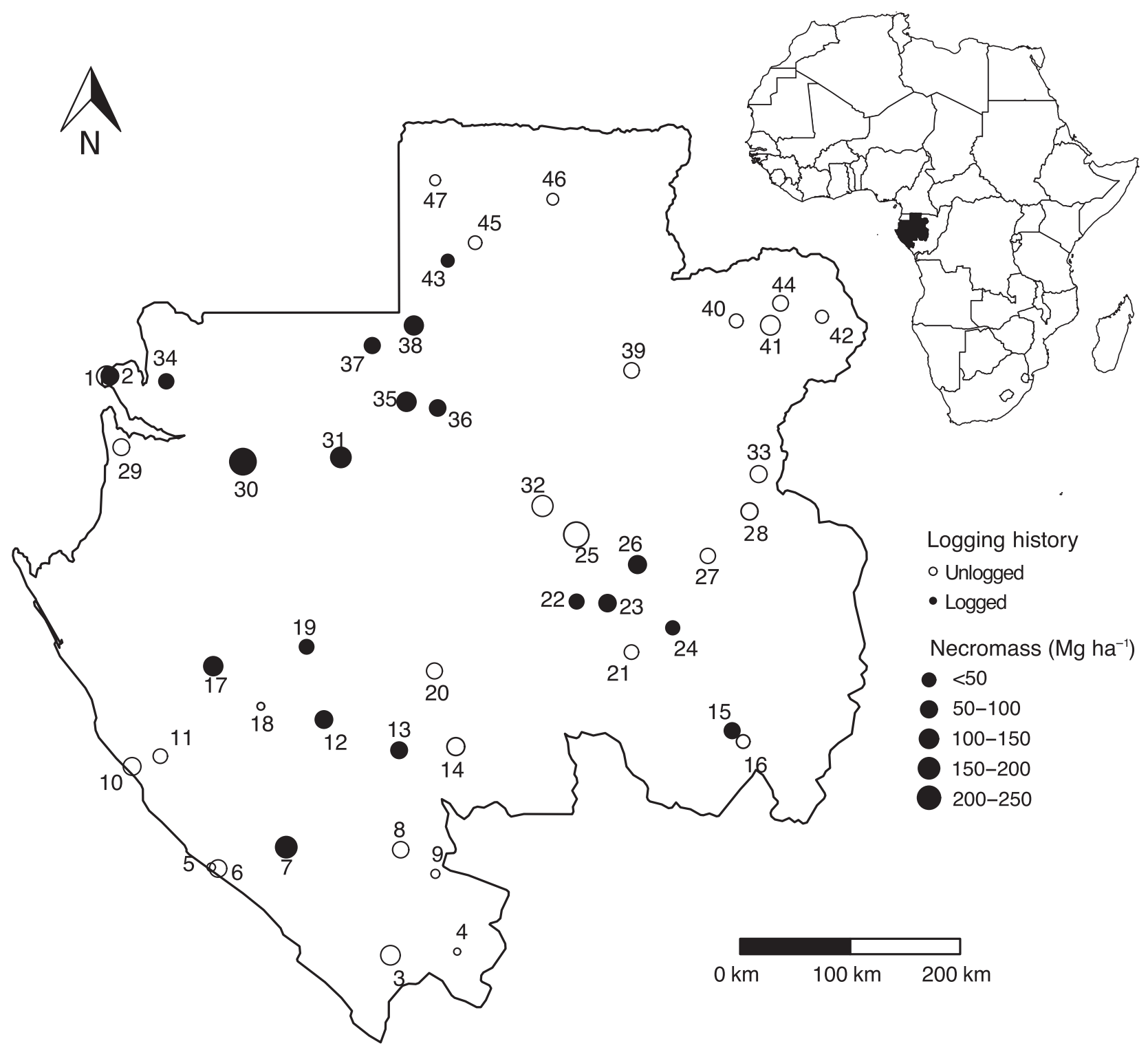

Fig. 1 Location of logged and unlogged sites in Gabon sampled for deadwood and AGB. The number next to each point is the site number (see Tables S3 and S5).

mass of each plug, we oven-dried all plugs at $65^{\circ} \mathrm{C}$ until subsequent daily weight measurements did not differ by more than $0.5 \%$ (Clark et al., 2002).

To adjust wood density for hollow space in deadwood, we estimated the proportion of void space in each radial section, defined as the empty regions in the radial section surrounded by at least $180^{\circ}$ of wood (Baker \& Chao, 2009). We used digital photos of the radial sections and ImageJ (rsb.info.nih.gov/ij/) to measure the total area and void area of each section (Chao et al., 2008). We divided the void space area by the total area of the radial section to derive the proportion of void space for the deadwood sample.

To account for the state of decay, we assigned each piece of fallen and standing deadwood to a decay class of 1-5. Decay class 1 represented newly fallen wood and decay class 5 represented rotten wood (Table S1). The five-decay class system often has low numbers of deadwood pieces in class 1 , whereas a three-decay class system yields similar estimates of stocks with better statistical power (Chao et al., 2008). Thus, we aggregated the five-decay class system to a three-decay class system for statistical analysis, using the method suggested by Chao et al. (2008). We combined decay classes one and two, retained decay class three, and combined decay classes four and five.

We calculated mean wood density by edaphic type and decay class to obtain density values that could be applied to all sites. We did not sample wood density for sites in swamp forest $(n=2)$, but instead used mean density by decay class across all sites. We adjusted mean wood density for each decay class/edaphic type combination by multiplying the 
mean estimated wood density by the proportion of the radial sections that were not void (also aggregated by decay class/ edaphic type; Chao et al., 2008) so that all wood densities are reported as void-adjusted density.

\section{Deadwood stocks and drivers}

We calculated necromass $\left(\mathrm{Mg} \mathrm{ha}^{-1}\right)$ for each transect and decay class combination by multiplying the volume of deadwood per ha (fallen + standing deadwood) by the wood density for the appropriate decay class and edaphic type combination. We summed the necromass of each decay class within a transect to obtain a transect-level necromass estimate, and then averaged across the transect-level necromass estimates, weighting by the length of the transects, to derive a site-level estimate of necromass. We calculated volume and necromass standard errors according to Keller et al. (2004) and Chao et al. (2008).

To determine the drivers of deadwood in Gabonese forests, we assembled information on disturbance, forest structure, and abiotic variables for each site. As described above, the disturbance history and edaphic type of each site was recorded in the field. We calculated forest structure variables for each site from the core NRI sampling data (unpublished data, Gabon National Resource Inventory). These variables include: aboveground live biomass (AGB), mean AGB per tree (AGB tree), basal areaweighted wood density (WD), density of stems (Stem density), density of stems $>60 \mathrm{~cm}$ (Large stems), mean tree diameter at breast height (Mean dbh), and mean tree height (Mean height). We chose temperature and precipitation values thought to have the greatest impact on deadwood stocks (for example, we reasoned that temperature in the coldest quarter would limit decomposition rates) and downloaded these values from the BIOCLIM database (Hijmans et al., 2005) at $30 \mathrm{~s}$ resolution. These variables included: mean temperature of the coldest quarter (Temp CQ), mean annual precipitation (MAP), and precipitation seasonality (Seasonality; see Table 1).

\section{Comparison to Neotropical deadwood studies}

We compared Gabon's deadwood stocks and N/AGB to 24 Neotropical studies (containing necromass estimates for 53 forests) and four Afrotropical studies (with estimates for five forests). Most of these studies (26 studies) came from a recent review of deadwood stocks (Palace et al., 2012), from which we used all studies of moist tropical forest except for two Neotropical moist forest studies that included fire disturbance (Cochrane et al., 1999) or did not provide information on disturbance history (Summers, 1998 cited in Palace et al., 2012). We also included two additional recent studies from African forests (Djomo et al., 2011; Gautam \& Pietsch, 2012). For all studies, we examined the original source literature to retrieve necromass estimates and forest type designations (primary, secondary, logged; Table S2).

\section{National estimate of deadwood stocks}

To derive an estimate of nationwide deadwood stocks, we multiplied the area of logged forest and unlogged forest by estimates of their average necromasses. Several estimates of total forested area in Gabon exist, ranging from 211260 to $236335 \mathrm{~km}^{2}$ (Laporte et al., 2007, FAO, 2010, 2015; OFAC, 2014; Sannier et al., 2016). No estimates exist for total logged forested area (including selectively logged forest area); however, Laporte et al. (2007) report a forested area of $211260 \mathrm{~km}^{2}$, of which $54 \%$ is logging concessions. Therefore, we use these values, treating forest concessions as logged forest, to estimate deadwood stocks at the national scale. To convert estimates of necromass to carbon, we assumed that $50 \%$ of necromass is made up of carbon (Elias \& Potvin, 2003).

\section{Statistical analysis}

The distributions of deadwood volume and necromass were slightly skewed, but we present all the above calculations of deadwood volume, necromass, and N/AGB as mean values (rather than median values) and use mean values in our statistical analysis to be consistent with previous studies (e.g., Chao et al., 2008; Djomo et al., 2011; Pfeifer et al., 2015). Using mean values did not change the inference of any of our statistics, and we present the mean and median for all summary values (e.g., total deadwood stocks), denoting the median in subscript (e.g., deadwood median $_{\text {). }}$

Table 1 Mean and range of abiotic and forest structure variables used to explain the variation in necromass and ratio of necromass to AGB

\begin{tabular}{llcc}
\hline Variable & Description & Mean (SD) & Range \\
\hline Temp CQ & Mean temperature coldest quarter $\left({ }^{\circ} \mathrm{C}\right)$ & $23.1(0.9)$ & $21.3-24.9$ \\
MAP & Mean annual precipitation $\left(\mathrm{mm} \mathrm{yr}^{-1}\right)$ & $1871.8(371.7)$ & $1361.0-3122.0$ \\
Seasonality & Precipitation seasonality $(\mathrm{CV})$ & $64.5(7.2)$ & $49.0-77.0$ \\
AGB & Aboveground live biomass $\left(\mathrm{Mg} \mathrm{ha}^{-1}\right)$ & $293.7(119.9)$ & $45.8-574.0$ \\
AGB tree & Mean AGB per tree $(\mathrm{Mg})$ & $0.7(0.3)$ & $0.2-1.3$ \\
WD & Basal area-weighted live wood density $\left(\mathrm{g} \mathrm{cm}^{-1}\right)$ & $0.6(0.1)$ & $0.4-0.7$ \\
Stem density & Stem density $\left(\right.$ stems ha $\left.{ }^{-1}\right)$ & $397.9(103.6)$ & $111.6-598.8$ \\
Large stems & Density of stems $\left.>60 \mathrm{~cm}^{(\text {stems ha }}{ }^{-1}\right)$ & $16.2(7.7)$ & $1.8-31.7$ \\
Mean dbh & Mean tree dbh $(\mathrm{cm})$ & $23.5(2.3)$ & $19.1-29.2$ \\
Mean height & Mean tree height $(\mathrm{m})$ & $20.2(5.1)$ & $8.5-31.3$ \\
Disturbance & Presence of logging $($ logged, unlogged) & - \\
\hline
\end{tabular}


We used ANOVA and Tukey post hoc tests to evaluate statistical differences in mean volume, necromass, and N/AGB across sites with different edaphic types and disturbance histories and to assess whether mean necromass and N/AGB vary between the Afrotropics and the Neotropics. Likewise, we used ANOVA and Tukey post hoc tests to examine differences in mean wood density by decay class, edaphic type, and disturbance history. To evaluate the impact of forest structure and abiotic variables on deadwood stocks, we performed bivariate linear regressions of each variable on necromass and on N/AGB. We then built multiple regression models with all variables, including logging history, to predict necromass and N/AGB. We used a backward, stepwise approach to reduce the full model, selecting the best model on the basis of the lowest Akaike information criterion (AIC) score. We examined plots of model residuals to assess the assumptions of normality and homoscedasticity and overall model fit. All calculations and statistical analyses were performed in $\mathrm{R}$ ( $\mathrm{R}$ Core Team 2015).

\section{Results}

\section{Deadwood volume}

We estimated deadwood stocks along $36.1 \mathrm{~km}$ of transects at a total of 47 sites (15 in primary forest, 13 in secondary forest, 19 in logged forest; Table S3). We measured deadwood volume at all sites for a total of 1360 fallen and 1090 standing pieces of deadwood. Mean deadwood volume in logged forests $\left(224 \mathrm{~m}^{3}\right.$ $\mathrm{ha}^{-1}$ ) was significantly higher than in unlogged forests $\left(125 \mathrm{~m}^{3} \mathrm{ha}^{-1}\right)$, but did not vary due to the edaphic type of the site (two-way ANOvA; logging: $F_{1,43}=7.536, \quad P=0.009$; edaphic type: $F_{2,43}=1.429$, $P=0.251)$.

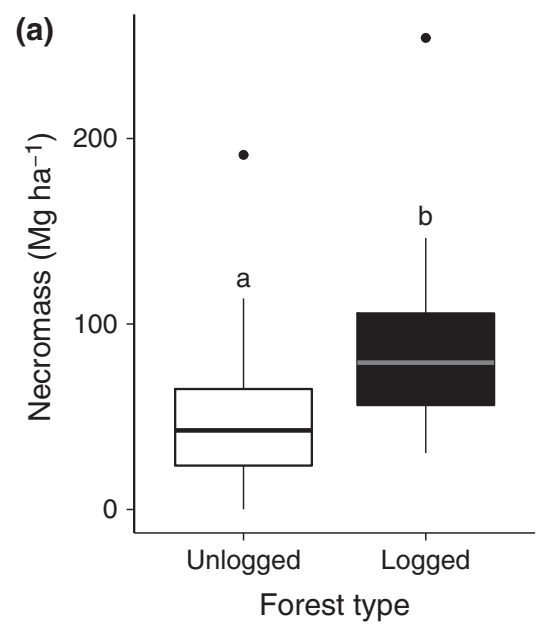

\section{Wood density and void space}

We measured deadwood void space and density at 16 sites, extracting 1131 wood samples from 416 pieces of deadwood in 11 terra firma forest sites and five seasonally flooded forest sites (Table S4). There was no significant difference in wood density between logged and unlogged forest while controlling for decay class and edaphic type. Mean wood density was significantly higher in terra firma forest than seasonally flooded forest, indicating that wood density estimates should be stratified by edaphic type (three-way ANOVA; logging: $F_{1,411}=2.989, P=0.085$; edaphic type: $F_{1,411}=18.679$, $P<0.001$; decay class: $\left.F_{2,411}=19.803, P<0.001\right)$. Void space made up a very small proportion of wood volume, with radial section void area ranging from $0.4 \%$ $2.4 \%$ of total area $(n=370$; Table $\mathrm{S} 4)$.

\section{Deadwood stocks and drivers}

Mean necromass for all sites was $65 \mathrm{Mg} \mathrm{ha}^{-1}$ (necromass $_{\text {median }}=57 \mathrm{Mg} \mathrm{ha}^{-1}$, range $=0.06-254 \mathrm{Mg} \mathrm{ha}^{-1}$; see Table S5 for the necromass and volume of each plot, and Table S6 for necromass summarized by decay class, edaphic type, and logging). Mean N/AGB for all sites was $23 \%\left(\mathrm{~N} / \mathrm{AGB}_{\text {median }}=18 \%\right.$, range $\left.=0.08-105 \%\right)$. We examined 11 drivers of variation in necromass and N/AGB (Table 1; Figs 2-4). Both necromass and N/ AGB were most strongly driven by logging history. Mean necromass was significantly higher in logged sites than in primary forest sites and marginally higher in logged sites than in secondary forest sites, with no significant difference between primary or secondary forest sites (ANOVA with Tukey post hoc test; forest type:

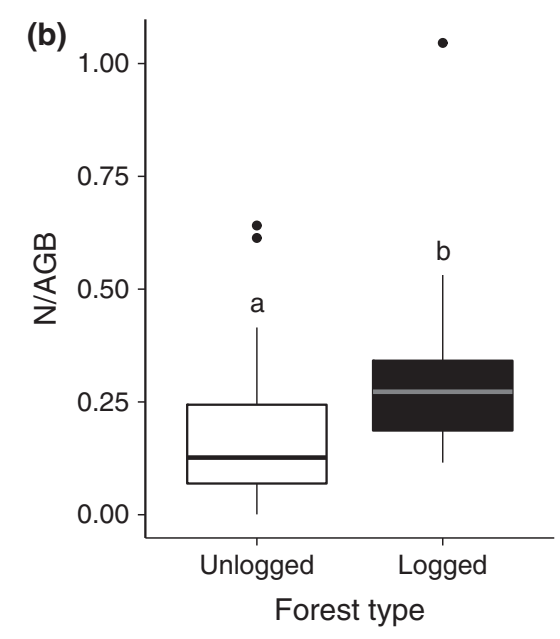

Fig. 2 Box plots comparing (a) necromass $\left(\mathrm{Mg} \mathrm{ha}^{-1}\right)$ and (b) the ratio of necromass to AGB (N/AGB) for unlogged and logged forests in Gabon. Necromass and N/AGB are significantly higher in logged forest than unlogged forest (Necromass: $t=-2.830, \mathrm{df}=45$, $P=0.007 ; \mathrm{N} / \mathrm{AGB}: t=-2.233, \mathrm{df}=45, P=0.031)$. 
$F_{2,44}=4.029, P=0.025$; secondary-primary: $P=0.900$; logged-primary: $\quad P=0.030 ; \quad$ logged-secondary: $P=0.109$; Fig. S1). Grouping primary and secondary sites as 'unlogged' sites, mean necromass was significantly higher in logged sites $\left(87 \mathrm{Mg} \mathrm{ha}{ }^{-1}\right)$ than unlogged sites (49 $\mathrm{Mg} \mathrm{ha}^{-1}$ ) on average (Fig. 2a).
N/AGB also varied significantly due to logging (Fig. 2b), with an average N/AGB of $30 \%$ in logged and $18 \%$ in unlogged sites.

Of our forest structure variables, only AGB and the density of large trees $(\mathrm{dbh}>60 \mathrm{~cm})$ were significantly related to necromass (Table 2; Figs 3 and S2). Each
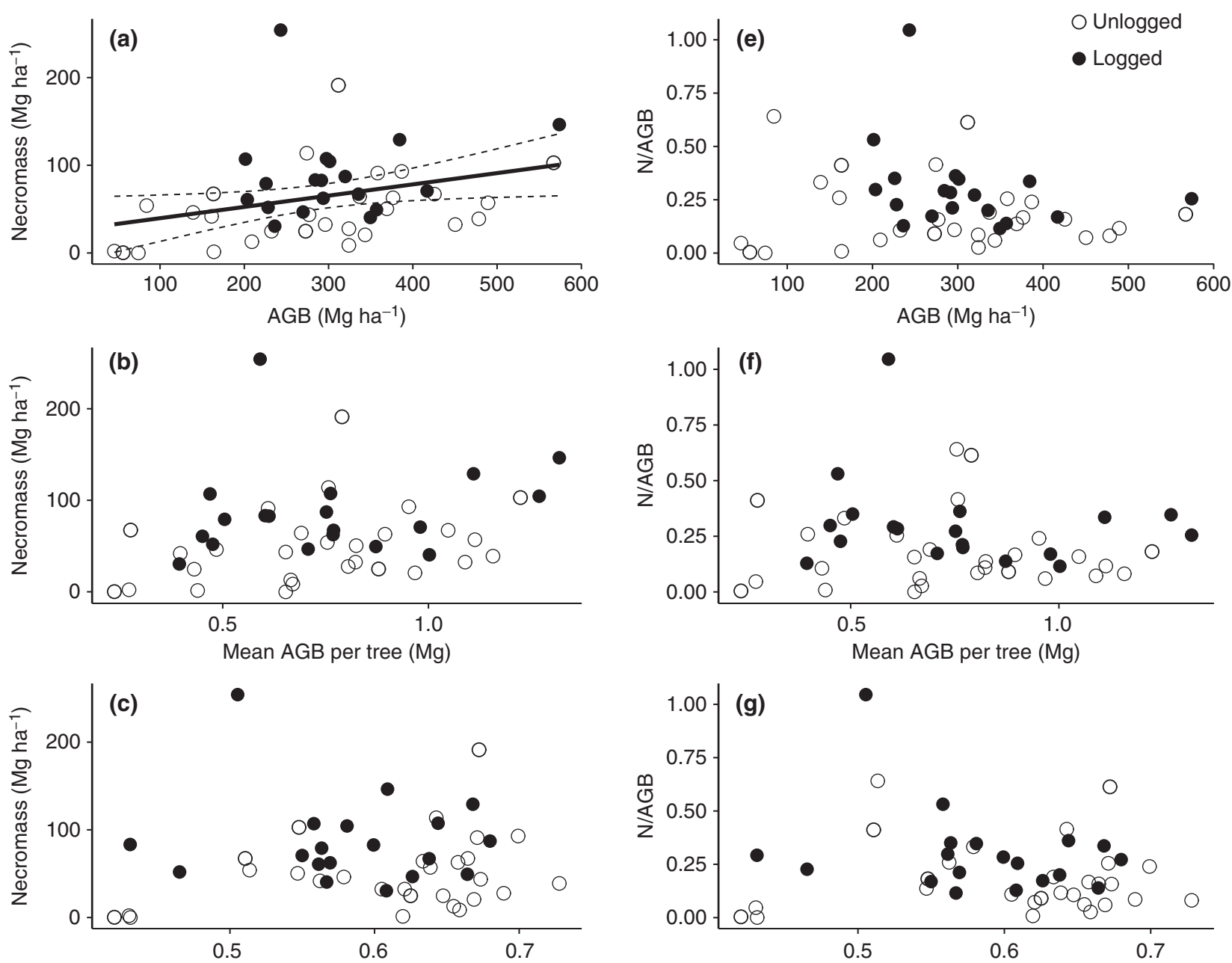

Basal area-weighted live wood density $\left(\mathrm{g} \mathrm{cm}^{-1}\right)$
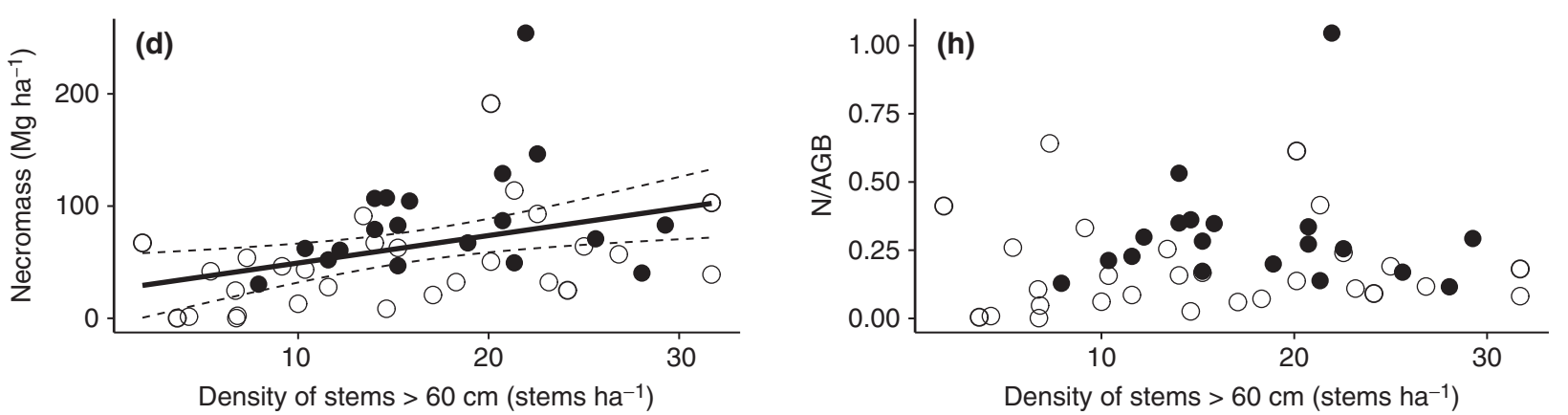

Fig. 3 Bivariate relationships between forest structure drivers of necromass $\left(\mathrm{Mg} \mathrm{ha}^{-1}\right)$ (a-d) and the ratio of necromass to AGB (N/AGB) (e-h) in Gabon. Significant relationships are depicted by the presence of the regression line (solid line) and $95 \%$ confidence intervals (dotted lines). See Table 2 for regression statistics. 
additional large tree increased necromass by $2.4 \mathrm{Mg}$ $\mathrm{ha}^{-1}$ on average. Although AGB and the density of large trees were highly correlated $(r=0.76, \mathrm{df}=45$, $P<0.001$ ), the density of large trees at a site was a better predictor of necromass than the AGB of the site. There were no significant relationships between necromass and any of the three abiotic variables (Table 2; Fig. 4), or two edaphic types (two-way ANOvA; edaphic type: $F_{2,43}=1.637, P=0.206$; logging: $F_{1,43}=7.121$, $P=0.011$ ). Unlike necromass, N/AGB was not significantly related to any of the forest structure variables, but was significantly related to MAP. N/AGB increases by $1.5 \%$ for every $100 \mathrm{~mm}$ increase in MAP.

The best multiple regression model of necromass included positive effects for logging history and the density of large trees; this model explained slightly more variation in necromass than a model substituting AGB for large trees. We present both models because measurements of AGB are more common than measurements of large stem density (Table 3). The best multiple regression model for N/AGB included positive effects for logging history and MAP (Table 3).

\section{National estimate of necromass stocks}

Using the mean necromass of all sites $\left(65 \mathrm{Mg} \mathrm{ha}^{-1}\right)$ and total forest area in Gabon (211 $\left.260 \mathrm{~km}^{2}\right)$, we estimated total deadwood stocks of $0.68 \mathrm{Pg} \mathrm{C}$ (deadwood $_{\text {median }}$ $=0.60 \mathrm{Pg} \mathrm{C}$ ). Stratifying by logged and unlogged forest, we estimated deadwood stocks of $0.24 \mathrm{Pg} \mathrm{C}$ (deadwood $\left._{\text {median }}=0.21 \mathrm{Pg} \mathrm{C}\right)$ in unlogged forests, $0.50 \mathrm{Pg} \mathrm{C}$
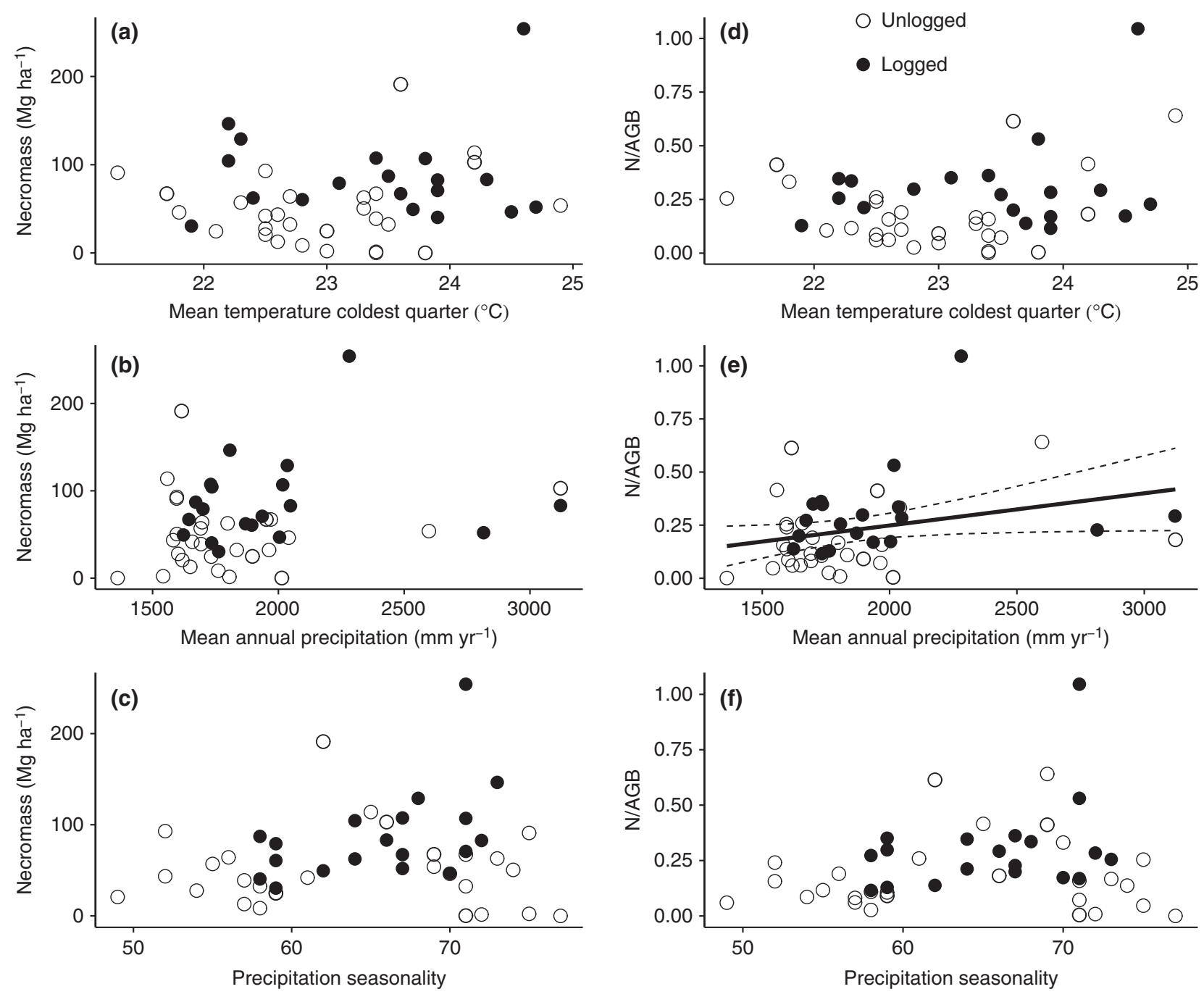

Fig. 4 Bivariate relationships between abiotic variables influencing necromass $\left(\mathrm{Mg} \mathrm{ha}^{-1}\right)(\mathrm{a}-\mathrm{C})$ and the ratio of necromass to $\mathrm{AGB}$ $(\mathrm{N} / \mathrm{AGB})(\mathrm{d}-\mathrm{f})$ in Gabon. Significant relationships are depicted by the presence of the regression line (solid line) and confidence intervals (dotted lines). See Table 2 for regression statistics. 
Table 2 Results of bivariate regression models evaluating the relationships between necromass and the ratio of necromass to live AGB (N/AGB) for abiotic variables (Temp CQ mean temperature of the coldest quarter, MAP - mean annual precipitation, Seasonality - precipitation seasonality) and forest structure variables (AGB - aboveground live biomass, AGB tree - mean AGB per tree, WD - basal area-weighted wood density, Stem density - density of stems, Large stems density of stems $>60 \mathrm{~cm}$, Mean dbh - mean tree diameter at breast height, Mean height - mean tree height). See Table 1 for descriptions of the variables influencing necromass (Variable). Items in bold are statistically significant $(P<0.05)$

\begin{tabular}{|c|c|c|c|c|c|}
\hline Variable & $\beta$ & SE & $t$ & $P$ & $R^{2}$ \\
\hline \multicolumn{6}{|l|}{ Necromass } \\
\hline Temp CQ & 10.786 & 8.392 & 1.285 & 0.205 & 0.035 \\
\hline MAP & 0.028 & 0.019 & 1.467 & 0.149 & 0.046 \\
\hline Seasonality & 1.131 & 0.997 & 1.134 & 0.263 & 0.028 \\
\hline AGB & 0.129 & 0.058 & 2.225 & 0.031 & 0.099 \\
\hline AGB tree & 46.384 & 26.015 & 1.783 & 0.081 & 0.066 \\
\hline WD & 46.365 & 94.423 & 0.491 & 0.626 & 0.005 \\
\hline Stem density & 0.097 & 0.069 & 1.409 & 0.166 & 0.042 \\
\hline Large stems & 2.447 & 0.877 & 2.790 & 0.008 & 0.147 \\
\hline Mean dbh & 4.116 & 3.143 & 1.309 & 0.197 & 0.037 \\
\hline Mean height & 1.905 & 1.390 & 1.370 & 0.177 & 0.040 \\
\hline \multicolumn{6}{|l|}{$\mathrm{N} / \mathrm{AGB}$} \\
\hline Temp CQ & 0.062 & 0.032 & 1.911 & 0.062 & 0.075 \\
\hline MAP & $1.5 \mathrm{e}-04$ & $7.38 \mathrm{e}-05$ & 2.053 & 0.046 & 0.086 \\
\hline Seasonality & 0.005 & 0.004 & 1.274 & 0.209 & 0.035 \\
\hline AGB & $-1.94 \mathrm{e}-04$ & 2.37e-04 & -0.816 & 0.419 & 0.015 \\
\hline AGB tree & -0.060 & 0.105 & -0.567 & 0.573 & 0.007 \\
\hline WD & -0.348 & 0.368 & -0.944 & 0.350 & 0.019 \\
\hline Stem density & 0.000 & 0.000 & 0.212 & 0.833 & 0.001 \\
\hline Large stems & 0.002 & 0.004 & 0.431 & 0.669 & 0.004 \\
\hline Mean dbh & -0.004 & 0.013 & -0.278 & 0.782 & 0.002 \\
\hline Mean height & -0.002 & 0.006 & -0.360 & 0.720 & 0.003 \\
\hline
\end{tabular}

(deadwood $\left._{\text {median }}=0.45 \mathrm{Pg} \mathrm{C}\right)$ in logged forest, and $0.74 \mathrm{Pg} \mathrm{C}\left(\right.$ deadwood $\left._{\text {median }}=0.66 \mathrm{Pg} \mathrm{C}\right)$ nationally. We did not quantify deadwood stocks in plantations or mangrove forests, but together, these make up $<1 \%$ of the forested area in Gabon (FAO, 2010).

\section{Discussion}

To our knowledge, this is the largest study of deadwood stocks in the tropics (47 sites and $36 \mathrm{~km}$ of line transects) and the first modern study focused on deadwood in Central Africa. Of all the drivers we examined, disturbance from selective logging most strongly influenced the deadwood pool, nearly doubling stocks relative to unlogged forests. Large trees $(>60 \mathrm{~cm} \mathrm{dbh})$ played a secondary role in determining deadwood stocks; forests with many large trees contained higher necromass than those with fewer large trees.
Table 3 Results of the most parsimonious multiple regression models (see Materials and methods). We conducted separate models using AGB as a predictor (Necromass-AGB) and the number of large trees as a predictor (Necromass-LS), because these variables were strongly correlated. In model N/ AGB, the ratio of necromass to AGB is treated as the response variable

\begin{tabular}{lcllll}
\hline \multicolumn{1}{c}{$\beta$} & SE & $t$ & $P$ & $R^{2}$ \\
\hline Necromass-LS & & & & & \\
$\quad$ Logged & 32.6 & 13.079 & 2.492 & 0.017 & 0.128 \\
$\quad$ Large stems & 2.1 & 0.844 & 2.449 & 0.018 & 0.125 \\
Full model & & $F_{2,44}=7.446$ & & 0.002 & 0.253 \\
\multicolumn{1}{l}{} & & & & & \\
Necromass-AGB & & & & & \\
Logged & 36.0 & 13.099 & 2.747 & 0.009 & 0.141 \\
AGB & 0.12 & 0.054 & 2.139 & 0.038 & 0.090 \\
Full model & & $F_{2,44}=6.608$ & & 0.003 & 0.231 \\
& & & & & \\
N/AGB & & & & & \\
Logged & 0.10 & 0.055 & 1.857 & 0.070 & 0.083 \\
MAP & $1.2 \mathrm{e}-04$ & $7.4 \mathrm{e}-05$ & 1.647 & 0.107 & 0.069 \\
Full model & & $F_{2,44}=3.945$ & & 0.027 & 0.152 \\
\hline
\end{tabular}

Extrapolating from our sites to the entirety of Gabon, we estimate that the country holds $0.74 \mathrm{Pg}$ of deadwood carbon, a substantial increase over the previous estimate of $0.20 \mathrm{Pg} \mathrm{C}$ (FAO, 2006). Gabonese forests store approximately $2.8 \mathrm{Pg} \mathrm{C}$ in live aboveground biomass (Saatchi et al., 2011); thus, deadwood contributes $21 \%$ of total (live and dead) aboveground forest carbon - an ecologically and, potentially, an economically significant proportion of national carbon stocks.

\section{Central African necromass and N/AGB estimates}

It is assumed that the ecological roles of deadwood in tropical forests are similar to those in temperate forests (Stokland et al., 2012), but most studies in tropical forests focus on deadwood as a carbon pool, and most occur outside of Central Africa. This disparity is reflected in the only previous national estimate for Gabon of $9 \mathrm{MgC} \mathrm{ha}^{-1}$, which was based on the available field data at the time (FAO, 2006). A global study of forest carbon estimated deadwood carbon in 'tropical Africa' as $26.29 \mathrm{Mg} \mathrm{C} \mathrm{ha}^{-1}$, using a network of plots to estimate AGB and a deadwood-AGB ratio of $12.7 \%$ (Pan et al., 2011). By comparison, our estimate of $34.87 \mathrm{Mg} \mathrm{C} \mathrm{ha}^{-1}$ is 3.8 and 1.3 times higher than the earlier estimates, underscoring the importance of field measurements of deadwood and explicitly considering the effects of selective logging.

Previous estimates of Central African deadwood stocks come from four studies, only two after 1960, that are either limited in spatial extent or not focused on 
necromass. In Cameroon, Djomo et al. (2011) reported necromass of $5 \mathrm{Mg} \mathrm{ha}^{-1}$ in primary forest and $14.4 \mathrm{Mg}$ $\mathrm{ha}^{-1}$ in logged forests (assuming necromass is $50 \%$ carbon). In Monts Birougou National Park, Gabon, Gautam \& Pietsch (2012) reported deadwood carbon for 18 plots, ranging from 8 to $62 \mathrm{Mg} \mathrm{ha}^{-1}$ with a mean of $29 \mathrm{Mg} \mathrm{ha}^{-1}$. Results from both of these studies tend to be lower than our results; but neither study employed standard methods used in recent tropical studies, which generally follow Keller et al. (2004) (e.g., see Palace et al., 2012), and both studies sampled a more limited area. The disparity in results among studies could be caused by different methodologies, including quantifying deadwood in small plots or using point sampling inventory method, or because of sampling extent (Djomo et al., 2011; Gautam \& Pietsch, 2012).

\section{Drivers of deadwood stocks}

Logging strongly affected deadwood stocks across Gabon, confirming results of previous studies (Keller et al., 2004; Palace et al., 2007; Pfeifer et al., 2015). Logged sites in Gabon contained on average $38 \mathrm{Mg}$ $\mathrm{ha}^{-1}$ more necromass than unlogged sites. Simply knowing whether a site is logged facilitates the prediction of deadwood stocks, but additional information such as time since the site was logged, logging intensity, and frequency can further improve precision in necromass estimates (Pfeifer et al., 2015). Because logging techniques and intensities can vary among tropical regions, future work in Central Africa should integrate information on timber extraction into models for estimating deadwood stocks.

After disturbance history, AGB and the density of large trees were the best predictors of deadwood stocks in Gabon, whereas basal area-weighted live wood density was not a significant predictor. Our results partially agree with those of a meta-analysis of Amazonian deadwood stocks, which found that all three of the above factors predicted necromass (Chao et al., 2009). The Amazon has an east-to-west gradient in which eastern forests have larger trees, higher wood density, and more deadwood than western forests (Baker et al., 2004; Chao et al., 2009), so that the effect of stem size and wood density on deadwood stocks are not easily disentangled from each other. Our results show only a response to tree size, suggesting that input size is a more important driver of deadwood stocks than wood density.

As we hypothesized, temperature had very little effect on deadwood stocks in Gabon. The limited variation in temperature of the coldest quarter across our study sites (range of $3.6{ }^{\circ} \mathrm{C}$, Table 1) is likely too small to have detectable effects on deadwood stocks.
Alternatively, increasing temperatures in the tropics accelerate rates of both productivity and decomposition (Chambers et al., 2000; Raich et al., 2006), so these opposing drivers may cancel each other out. In contrast to temperature, precipitation varies widely in Gabon with an $1800 \mathrm{~mm}$ west-to-east precipitation gradient. Even so, mean annual precipitation also did not strongly influence deadwood stocks. In our study, however, N/AGB had a very small, positive relationship with $\operatorname{MAP}\left(R^{2}=0.086\right.$; Table 2$)$, with a $1.5 \%$ increase in N/AGB for every $100 \mathrm{~mm}$ of precipitation. Precipitation in the tropics does not influence productivity (Malhi et al., 2004) or decomposition rates (Chambers et al., 2000); thus, outside of discrete extreme events such as severe droughts, deadwood stocks and N/AGB should be constant across a range of precipitation. Similar to our study, two landscape-scale studies also found no effect of temperature or precipitation on deadwood stocks (Martins et al., 2015; Pfeifer et al., 2015).

\section{Comparison to the Neotropics}

Central African forests might store less necromass than Neotropical forests because of a less intense disturbance regime, might store more necromass due to the presence of larger trees, or might have similar necromass if these drivers cancel each other. To understand this relationship, we compared our results to data from humid tropical forests in a recent review (Palace et al., 2012). Deadwood stocks were similar between the two regions, and stocks responded similarly to logging: logged sites contained significantly more necromass than unlogged sites in both regions, but necromass in logged and unlogged sites did not differ between regions (Fig. 5a). N/AGB, however, was significantly higher in the Neotropics than in Gabon even after removing five potential outliers (sites with N/AGB $>200 \%$ ), and N/AGB was not related to logging history in either region (Fig. 5b). We suspect that in the Amazon, greater rates of disturbance, in combination with higher decomposition rates due to the smaller size of the trees, lead to deadwood pool sizes similar to Central Africa. Greater disturbance in the Amazon is also consistent with the higher ratio of $N / A G B$ in the Neotropics compared to the Afrotropics.

\section{Implications to national management of carbon}

Oil palm plantations represent an important and expanding land-use type in the tropics (Phalan et al., 2013). Gabon, like other Central African countries, plans to grow its oil palm plantations (M.E.L \& L.J.T.W., National Land use Plan, cited in Burton et al., 2016), potentially releasing high levels of carbon 

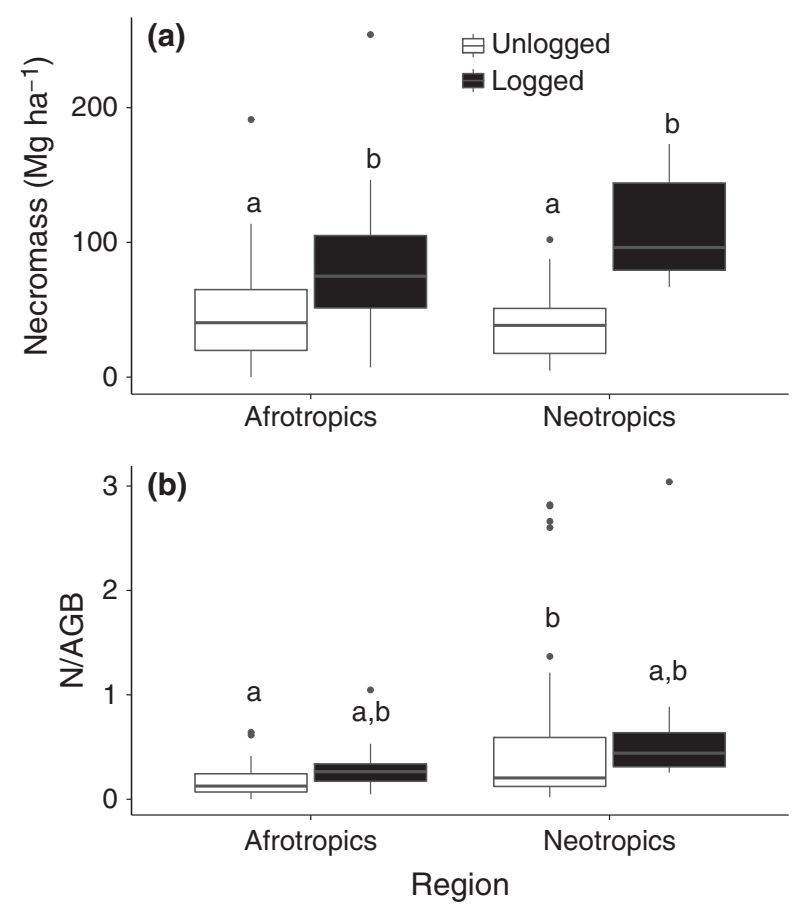

Fig. 5 Comparison of (a) necromass stocks and (b) ratio of necromass to AGB (N/AGB) in logged and unlogged forests in the Afrotropics and Neotropics. Values are from this study, sites located in humid tropical forest from Palace et al. (2012), Djomo et al. (2011), and Gautam \& Pietsch (2012) (see Tables S2 and S5). Necromass is significantly higher in logged than unlogged forests, but does not differ significantly between continents (two-way ANOVA; continent: $F_{1,100}=1.315, P=0.254$; logging: $\left.F_{1,100}=35.712, P<0.001\right)$. N/AGB is significantly higher in Neotropical than Afrotropical forests (two-way ANOVA; continent: $F_{1,97}=10.975, P=0.001$; logging: $\left.F_{1,97}=1.103, P=0.296\right)$.

emissions through land conversion. Burton et al. (2016) estimated that conversion of logged forest to a 31800 ha palm plantation would release $1.50 \mathrm{Tg}$ of aboveground $\mathrm{C}$ and recommended restricting plantation development to the lowest quartile of forest carbon densities. Using our deadwood ratio of $30 \%$ for logged forest, we estimate that this 'agriculturally available' land would store approximately $35 \mathrm{Mg} \mathrm{C} \mathrm{ha}^{-1}$ of deadwood. A more lenient standard, permitting development up to the second lowest quartile of carbon densities, would release $47 \mathrm{Mg} \mathrm{C} \mathrm{ha} \mathrm{ha}^{-1}$ of deadwood. The emissions consequences of deadwood carbon depend on the fate of the deadwood (burned, cleared, bulldozed, etc.), but it is important to recognize that significant amounts of carbon exist outside of the aboveground biomass pool and must be considered in policy and land management decisions.

Accurate estimation of forest carbon pools is a key component of the IPCC guidelines for national greenhouse gas (GHG) inventories. The most accurate GHG inventory approach uses regional models parameterized with country-specific data, coupled with a national forest inventory (Birdsey et al., 2013). Few countries have the capacity to implement this approach, and instead rely on regional default values of carbon stocks provided by the IPCC. However, citing lack of data, the IPCC does not provide regional estimates for deadwood (see Table 2.2 in IPCC, 2006). As we have discussed above, lack of data-based regional default values can lead to significant underestimation of these carbon stocks. In total, employing the FAO value would underestimate total aboveground biomass (live plus dead) by more than $15 \%$. Although we advocate using separate ratios for logged and unlogged forest, we recognize that accurate assessments of the extent of selectively logged forest is often not available. Therefore, we provide an estimate of $32.5 \mathrm{Mg} \mathrm{C} \mathrm{ha-}{ }^{-1}$ for average deadwood density across all forests. This represents the first systematic, regional estimate of tropical deadwood stocks that can be applied to Central African GHG inventories.

Forest degradation from selective logging can damage vegetation, reduce ecosystem function, and impact biodiversity (Asner et al., 2005). We show that selective logging also results in significantly higher deadwood pools, nearly twice those in unlogged forests - the signature of logging is the most important and consistent driver of deadwood stocks in Gabon. A similar finding in the Neotropics suggests this is a global pattern in humid tropical forests. We therefore recommend that national carbon inventories in Central Africa account for selectively logged forests, using default values of 43.5 and $24.5 \mathrm{Mg} \mathrm{C} \mathrm{ha}^{-1}$ for logged and unlogged forests, respectively. When estimating necromass as a ratio of biomass, inventories should also use two separate ratios, one for logged forests $(30 \%)$ and one for unlogged forests (18\%). Deadwood makes up an important fraction of tropical forest carbon stocks, but its contribution varies with land-use activities and trees size, highlighting the need to study the drivers of carbon stocks for accurate global carbon accounting and effective climate change mitigation.

\section{Acknowledgements}

The Gabon National Climate Change Council authorized the establishment of the National Resource Inventory, which was supported by OLAM-Gabon and the US SilvaCarbon program. The National Center for Scientific Research and Technology (CENAREST) provided permission to conduct this work, and the Gabon Parks Agency (ANPN) provided administrative and logistical support. Special thanks to J.-G. Diof, A. Maroga, C. Mbina, P. Nguema, A. Nkoghe Nze, M. Nziengui, C. Tayo, C. Tchambela, A. Yebe, J. Chin, and the ANPN field team for their contributions to project implementation. We thank C. Nuñez, S. 
Saatchi, K. Wilcox, and two anonymous reviewers for constructive comments that improved the manuscript. The authors have no conflict of interests to declare.

\section{References}

Asner GP, Knapp DE, Broadbent EN, Oliveira PJC, Keller M, Silva JN (2005) Selective logging in the Brazilian Amazon. Science, 310, 480-482.

Asner GP, Powell GV, Mascaro J et al. (2010) High-resolution forest carbon stocks and emissions in the Amazon. Proceedings of the National Academy of Sciences, 107, 16738-16742.

Baccini A, Goetz SJ, Walker WS et al. (2012) Estimated carbon dioxide emissions from tropical deforestation improved by carbon-density maps. Nature Climate Change, 2, 182-185.

Baker TR, Chao KJ (2009) Manual for coarse woody debris measurement in RAINFOR plots.

Baker TR, Phillips OL, Malhi Y et al. (2004) Variation in wood density determines spatial patterns in Amazonian forest biomass. Global Change Biology, 10, 545-562.

Baker TR, Coronado ENH, Phillips OL, Martin J, van der Heijden GM, Garcia M, Espejo JS (2007) Low stocks of coarse woody debris in a southwest Amazonian forest. Oecologia, 152, 495-504.

Bastin J-F, Barbier N, Réjou-Méchain M et al. (2015) Seeing Central African forests through their largest trees. Scientific Reports, 5, 13156. doi:10.1038/srep13156.

Bell G, Kerr A, McNickle D, Woollons R (1996) Accuracy of the line intersect method of post-logging sampling under orientation bias. Forest Ecology and Management, 84, 23-28.

Birdsey R, Angeles-Perez G, Kurz WA et al. (2013) Approaches to monitoring changes in carbon stocks for REDD+. Carbon Management, 4, 519-537.

Bradford MA, Warren Ii RJ, Baldrian P et al. (2014) Climate fails to predict wood decomposition at regional scales. Nature Climate Change, 4, 625-630.

Brown S, Gaston G (1996) Estimates of biomass density for tropical forests. Biomass Burning and Global Change, 1, 133-139.

Burton ME, Poulsen JR, Lee ME, Medjibe VP, Stewart CG, Venkataraman A, White LJ (2016) Reducing carbon emissions from forest conversion for oil palm agriculture in Gabon. Conservation Letters.

Chambers JQ, Higuchi N, Schimel JP, Ferreira LV, Melack JM (2000) Decomposition and carbon cycling of dead trees in tropical forests of the central Amazon. Oecologia, 122, 380-388.

Chambers JQ, dos Santos J, Ribeiro RJ, Higuchi N (2001) Tree damage, allometric relationships, and above-ground net primary production in central Amazon forest. Forest Ecology and Management, 152, 73-84.

Chambers J, Fisher R, Hall J, Norby RJ, Wofsy SC (2012) Research Priorities for Tropical Ecosystems Under Climate Change Workshop.

Chao K-J, Phillips OL, Baker TR (2008) Wood density and stocks of coarse woody debris in a northwestern Amazonian landscape. Canadian Journal of Forest Research, 38, 795-805.

Chao K-J, Phillips OL, Baker TR et al. (2009) After trees die: quantities and determinants of necromass across Amazonia. Biogeosciences, 6, 1615-1626.

Chave J, Muller-Landau HC, Baker TR, Easdale TA, ter Steege H, Webb CO (2006) Regional and phylogenetic variation of wood density across 2456 neotropical tree species. Ecological Applications, 16, 2356-2367.

Clark DB, Clark DA, Brown S, Oberbauer SF, Veldkamp E (2002) Stocks and flows of coarse woody debris across a tropical rain forest nutrient and topography gradient. Forest Ecology and Management, 164, 237-248.

Cochrane MA, Alencar A, Schulze MD, Souza CM, Nepstad DC, Lefebvre P, Davidson EA (1999) Positive feedbacks in the fire dynamic of closed canopy tropical forests. Science, 284, 1832-1835.

Dixon RK, Solomon AM, Brown S, Houghton RA, Trexier MC, Wisniewski J (1994) Carbon pools and flux of global forest ecosystems. Science, 263, 185-190.

Djomo AN, Knohl A, Gravenhorst G (2011) Estimations of total ecosystem carbon pools distribution and carbon biomass current annual increment of a moist tropical forest. Forest Ecology and Management, 261, 1448-1459.

Elias M, Potvin C (2003) Assessing inter-and intra-specific variation in trunk carbon concentration for 32 neotropical tree species. Canadian Journal of Forest Research, 33 $1039-1045$.

FAO (2006) Global Forest Resources Assessment 2005: progress towards sustainable forest management. Food and Agriculture Organization of the United Nations (FAO), Rome.

FAO (2010) Global Forest Resources Assessment 2010. Food and Agriculture Organization of the United Nations (FAO), Rome.
FAO (2015) Global Forest Resources Assessment 2015. Food and Agriculture Organization of the United Nations (FAO), Rome.

Gale N (2000) The aftermath of tree death: coarse woody debris and the topography in four tropical rain forests. Canadian Journal of Forest Research, 30, 1489-1493.

Gautam S, Pietsch SA (2012) Carbon pools of an intact forest in Gabon. African Journal of Ecology, 50, 414- 427.

Gibbs HK, Brown S, Niles JO, Foley JA (2007) Monitoring and estimating tropical forest carbon stocks: making REDD a reality. Environmental Research Letters, 2, 045023.

Harmon ME, Franklin JF, Swanson FJ et al. (1986) Ecology of coarse woody debris in temperate ecosystems. Advances in Ecological Research, 15, 302.

Hijmans RJ, Cameron SE, Parra JL, Jones PG, Jarvis A (2005) Very high resolution interpolated climate surfaces for global land areas. International Journal of Climatol ogy, 25, 1965-1978.

Houghton RA, Lawrence KT, Hackler JL, Brown S (2001) The spatial distribution of forest biomass in the Brazilian Amazon: a comparison of estimates. Global Change Biology, 7, 731-746.

IPCC (2003) Good practice guidance for land use, land-use change and forestry/The Intergovernmental Panel on Climate Change. Ed. by Jim Penman. Hayama, Kanagawa.

IPCC (2006) IPCC Guidelines for National Greenhouse Gas Inventories. Volume 4. Agriculture, Forestry and Other Land Uses. IPCC, Institute for Global Environmental Strategies, Hayama, Japan.

Keller M, Palace M, Asner GP, Pereira R, Silva JNM (2004) Coarse woody debris in undisturbed and logged forests in the eastern Brazilian Amazon. Global Change Biology, 10, 784-795.

Laporte NT, Stabach JA, Grosch R, Lin TS, Goetz SJ (2007) Expansion of industrial logging in central Africa. Science, 316, 1451.

Larjavaara M, Muller-Landau HC (2012) Temperature explains global variation in biomass among humid old-growth forests. Global Ecology and Biogeography, 21, 998-1006.

Lewis SL, Lopez-Gonzalez G, Sonké B et al. (2009) Increasing carbon storage in intact African tropical forests. Nature, 457, 1003-1006.

Lewis SL, Sonké B, Sunderland T et al. (2013) Above-ground biomass and structure of 260 African tropical forests. Philosophical Transactions of the Royal Society of London B: Biological Sciences, 368, 20120295.

Malhi Y, Baker TR, Phillips OL et al. (2004) The above-ground coarse wood productivity of 104 neotropical forest plots. Global Change Biology, 10, 563-591.

Malhi Y, Wood D, Baker TR et al. (2006) The regional variation of aboveground live biomass in old-growth Amazonian forests. Global Change Biology, 12, $1107-1138$

Malhi Y, Adu-Bredu S, Asare RA, Lewis SL, Mayaux P (2013) African rainforests: past, present and future. Philosophical Transactions of the Royal Society of London B Biological Sciences, 368, 20120312

Martins DL, Schietti J, Feldpausch TR et al. (2015) Soil-induced impacts on fores structure drive coarse woody debris stocks across central Amazonia. Plant Ecology and Diversity, 8, 229-241.

McGee GG, Leopold D, Nyland RD (1999) Stuctrural characteristics of old-growth, maturing, and partially cut northern hardwood forests. Ecological Applications, 9, 1316-1329.

Mayaux P, Richards T, Janodet E (1999) A vegetation map of Central Africa derived from satellite imagery. Journal of Biogeography, 26, 353-366.

Medjibe VP, Putz FE, Starkey MP, Ndouna AA, Memiaghe HR (2011) Impacts of selective logging on above-ground forest biomass in the Monts de Cristal in Gabon. Forest Ecology and Management, 262, 1799-1806.

Negrón-Juárez RI, Chambers JQ, Guimaraes G et al. (2010) Widespread Amazon forest tree mortality from a single cross-basin squall line event. Geophysical Research Letters, 37, L16701. doi:10.1029/2010GL043733.

OFAC (2014) The forests of the Congo Basin - State of the forest 2013. Observatoire des Forêts d'Afrique centrale of the Commission des Forêts d'Afrique centrale, Rome.

Osone Y, Toma T, Warsudi S, Sato T (2016) High stocks of coarse woody debris in a tropical rainforest, East Kalimantan: coupled impact of forest fires and selective logging. Forest Ecology and Management, 374, 93-101.

Palace M, Keller M, Asner GP, Silva JNM, Passos C (2007) Necromass in undisturbed and logged forests in the Brazilian Amazon. Forest Ecology and Management, 238, 309-318.

Palace M, Keller M, Hurtt G, Frolking S (2012) A review of above ground necromass in tropical forests. In: Tropical Forests, (eds Sudarshana P, Nageswara-Rao M, Soneji JR), pp. 215-252. Intech. Available at: http://www.intechopen.com/books/ tropical-forests (accessed 15 February 2016).

Pan Y, Birdsey RA, Fang J et al. (2011) A large and persistent carbon sink in the world's forests. Science, 333, 988-993. 
Pfeifer M, Lefebvre V, Turner E et al. (2015) Deadwood biomass: an underestimated carbon stock in degraded tropical forests? Environmental Research Letters, 10, 044019 .

Phalan B, Bertzky M, Butchart SH, Donald PF, Scharlemann JP, Stattersfield AJ, Balmford A (2013) Crop expansion and conservation priorities in tropical countries. PLOS ONE, 8, e51759.

Phillips OL, Gentry AH (1994) Increasing turnover through time in tropical forests. Science, 263, 954-958.

Phillips OL, Aragão LE, Lewis SL et al. (2009) Drought sensitivity of the Amazon rainforest. Science, 323, 1344-1347.

Progar RA, Schowalter TD, Freitag CM, Morrell JJ (2000) Respiration from coarse woody debris as affected by moisture and saprotroph functional diversity in Western Oregon. Oecologia, 124, 426-431.

R Core Team (2015) R: A Language and Environment for Statistical Computing. Foundation for Statistical Computing, Vienna, Austria.

Raich JW, Russell AE, Kitayama K, Parton WJ, Vitousek PM (2006) Temperature influences carbon accumulation in moist tropical forests. Ecology, 87, 76-87.

Rice AH, Pyle EH, Saleska SR et al. (2004) Carbon balance and vegetation dynamics in an old-growth Amazonian forest. Ecological Applications, 14, 55-71.

Saatchi SS, Houghton RA, Dos Santos Alvala RC, Soares JV, Yu Y (2007) Distribution of aboveground live biomass in the Amazon basin. Global Change Biology, 13, 816-837.

Saatchi SS, Harris NL, Brown S et al. (2011) Benchmark map of forest carbon stocks in tropical regions across three continents. Proceedings of the National Academy of Sciences, 108, 9899-9904.

Sannier C, McRoberts RE, Fichet L-V (2016) Suitability of Global Forest Change data to report forest cover estimates at national level in Gabon. Remote Sensing of Environment, 173, 326-338.

Sassen M, Sheil D, Giller KE (2015) Fuelwood collection and its impacts on a protected tropical mountain forest in Uganda. Forest Ecology and Management, 354, 56-67.

Shen Y, Yu S, Lian J, Shen H, Cao H, Lu H, Ye W (2016) Tree aboveground carbon storage correlates with environmental gradients and functional diversity in a tropical forest. Scientific Reports, 6, 25304

Slik JW, Paoli G, McGuire K et al. (2013) Large trees drive forest aboveground biomass variation in moist lowland forests across the tropics. Global Ecology and Biogeography, 22, 1261-1271

Stokland JN, Siitonen J, Jonsson BG (2012) Biodiversity in Dead Wood. Cambridge University Press, New York.

Summers PM (1998) Estoque, decomposicao, e nutrientes da liteira grossa em floresta de terra firme, na Amazonia Central. Ciencias de Florestas Tropicais, Instituto Nacional de Pesquisas da Amazonia, Manaus, Brazil.
Van Wagner CE (1968) The line intersect method in forest fuel sampling. Fores Science, 14, 20-26.

Warren RJ, Bradford MA (2012) Ant colonization and coarse woody debris decomposition in temperate forests. Insectes Sociaux, 59, 215-221.

Warren WG, Olsen PF (1964) A line intersect technique for assessing logging waste. Forest Science, 10, 267-276.

Weedon JT, Cornwell WK, Cornelissen JHC, Zanne AE, Wirth C, Coomes DA (2009) Global meta-analysis of wood decomposition rates: a role for trait variation among tree species? Ecology Letters, 12, 45-56.

\section{Supporting Information}

Additional Supporting Information may be found in the online version of this article:

Figure S1 Box plots comparing (a) necromass stocks (Mg $\mathrm{ha}^{-1}$ ) and (b) the ratio of necromass to AGB (N/AGB) by forest type (primary, secondary, logged) in Gabon.

Figure S2 Bivariate relationships between biotic drivers of necromass $\left(\mathrm{Mg} \mathrm{ha}^{-1}\right)$ (a-c) and the ratio of necromass to AGB (N/AGB) (d-f) in Gabon.

Table S1 Decay class criteria.

Table S2 Estimates of Necromass and AGB from the literature.

Table S3 Characteristics of sample sites in Gabon.

Table S4 Wood density and void proportion of deadwood.

Table S5 Volume and necromass estimates for each sample site in Gabon.

Table S6 Necromass summarized by decay class, edaphic type, and logging. 